\title{
FINANČNÉ PYRAMÍDY A ICH REGULAČNÉ PERSPEKTÍVY*
}

\author{
L'UBOMÍR ČUNDERLÍK
}

\begin{abstract}
Financial Pyramids and their Regulatory Perspectives
It can be stated that there is no explicit regulation of the issue of financial pyramids in the legal order of the Slovak Republic or on European law level. In the legislation, it is possible to distinguish case-by-case whether it is a general prevention of financial pyramids or whether it is a regulation-specific prohibition regarding activities on the financial market. The national financial market supervisory authority in particular plays an important role in the field of protection. In the article, the author identifies the essential features of the pyramid schemes in general, subsequently in the light of financial market regulation.
\end{abstract}

Keywords: financial pyramids; Ponzi scheme; pyramids on the financial market; typology of pyramid schemes; prevention and investor protection

Kl’účové slová: finančné pyramídy; Ponziho schéma; pyramídy na finančnom trhu; typológia pyramídových schém; prevencia a ochrana investora

DOI: $10.14712 / 23366478.2020 .22$

\section{1. ÚVOD A STRUČNÁ HISTÓRIA PYRAMÍDOVÝCH SCHÉM}

V tridsiatych rokoch 17 . storočia sa objavila prvá podrobne zdokumentovaná špekulatívna investičná bublina, tzv. tulipánová horúčka v Spojených nizozemských provinciách, ktorá sa týkala tulipánových cibuliek. Spočívala v spontánnom masovom správaní, ktoré akcelerovalo do nereálnych cien v rámci ponuky a dopytu po tejto komodite. Išlo o prirodzenú pyramídu, bez úmyslu organizátora obohatit' sa na obchodníkoch zapojených do tulipánovej burzy, a teda nepredstavovala vedomú trhovú manipuláciu s komoditou.

Prvú známu pyramídovú schému organizovanú konkrétnou osobou, ktorá vychádzala z podvodných investičných sl’ubov voči verejnosti, zosnoval v roku 1920 Charles

\footnotetext{
* Článok parciálne vychádza z obsahu všeobecnej časti prednášky autora s názvom „Regulatory Aspects of Financial Pyramids - Supervisory Point of View“, realizovanej na pozvanie Programového úradu OBSE v Nur-Sultane, dňa 12. júla 2019 v Almate, Kazachstane v rámci podujatia „Identifying and countering the financial pyramids".
} 
Ponzi, zakladatel' pyramídovej schémy v USA v modernom ponímaní. Ch. Ponzi, ktorého priezvisko sa stalo neskôr synonymom pre typovo obdobné zavádzajúce investičné schémy, bol vystavitel'om (emitentom) nezabezpečených dlžných úpisov, ktoré mali byt' ich vlastníkom vyplácané z výnosov dosiahnutých obchodovaním s medzinárodnými kupónmi na odpovedné poštové zásielky, pričom deklaroval (sl'uboval) investičný výnos vo výške úroku $50 \%$ za štvrt'rok. Jeho pôvodná schéma síce bola založená na legitímnej cenovej arbitráži medzinárodných kupónov, ale čoskoro začal rozdel'ovat' peniaze nových investorov na realizáciu platieb v prospech skorších investorov a sebe samému. Takouto svojou činnost'ou zhromaždil takmer 10 miliónov USD. ${ }^{1}$ Pôvodná forma Ponziho schémy bola z hl'adiska svojej podstaty investičným programom založeným na pevnom výnose. Napriek odstupu času, odkedy sa tento typ pyramídovej schémy objavil v moderných dejinách, je možné aj v súčasnosti považovat' Ponziho schému s pevným výnosom za stále bežnú, vel'mi populárnu a jednoduchú distribučnú investičnú schému, ktorá využíva nedostatočnú finančnú gramotnost' verejnosti. Odhliadnuc od klasickej fixne orientovanej schémy sa povaha a metódy pyramídových schém postupom času vyvíjali. ${ }^{2}$ Napriek tomu, že investičné pyramídy sa z času na čas vyskytnú aj v priestore rozvinutých členských krajín Európskej únie, doteraz absentuje relevantná európska legislatíva ako aj harmonizácia špeciálnych (zásahových) kompetencií v tejto oblasti pre dohliadacie autority (resp. orgány dohl'adu, dozoru a inšpekcie) na národnej úrovni a úrovni Európskej únie (napríklad pre európsku dohliadaciu agentúru EBA - Európsky orgán pre bankovníctvo).

\section{DEFINÍCIA A CHARAKTERISTICKÉ ZNAKY PYRAMÍDOVÝCH SCHÉM}

Možno konštatovat', že v právnom poriadku Slovenskej republiky ani v európskom práve neexistuje všeobecná uznávaná, resp. jednotná definícia pyramídovej schémy (ani jednotná terminológia, ktorá by sa v súvislosti s touto problematikou používala). V anglickom jazyku sa používajú rôzne označenia, ako napríklad „Ponzi scheme“, „pyramid game“, „pyramid scheme“ alebo „,airplane game“. Vnútroštátne regulačné predpisy sa značne odlišujú v spôsobe pomenovania alebo opísania konania napĺñajúceho znaky pyramídovej schémy, obvykle rezignujú na vyčerpávajúci opis a obmedzia sa na generálny zákaz určitého konania, ktoré koliduje s licencovanou

1 K tomu pozri SHILLER, R. J. Investiční horečka - iracionální nadšení na kapitálových trzích (český preklad). Praha: Grada Publishing, a. s., 2010, s. 102-103, alebo heslo „Ponzi scheme“ In: Wikipedia [online]. [cit. 2020-06-03]. Dostupné na: https://en.wikipedia.org/wiki/Ponzi_scheme.

2 Napríklad v súčasnosti existujú aj schémy, ktoré využívajú sociálne siete a virtuálne meny na pritiahnutie investorov. V tejto súvislosti najväčšou Ponziho schémou v roku 2019 bol Token „Plus“ v Č́ne, Kórei a Japonsku, ktorý akumuloval bitcoiny v hodnote 185 mil. USD. Pozri ORCUTT, M. Millions of people fell for crypto-Ponzi schemes in 2019. In: MIT Technology Review [online]. January 30. 2020 [cit. 2020-06-05]. Dostupné na: https://www.technologyreview.com/2020/01/30/275964 /cryptocurrency-ponzi-scams-chainalysis/. Na kapitálovom trhu ide o mediálne známy prípad prvého desat'ročia 21. storočia pána Bernarda L. Madoffa. 
činnost'ou (napríklad na finančnom trhu) a ktoré môže v dôsledku toho viest' k zavádzaniu investorskej verejnosti a následne k strate jej investícií.

Domnievame sa, že v optike regulačného prístupu (t. j. z pohl'adu dohliadacieho orgánu) v priestore Európskej únie nie je ani možné a pravdepodobne ani vhodné poskytnút' komplexnú definíciu, pretože podvodné konania sa (nielen na finančnom trhu) neustále zdokonal'ujú a vyvíjajú, pričom neustále nadobúdajú rôzne podoby a formy, ktoré sa môžu vymykat' štandardnej typizácii jednotlivých modelov a vybočovat' z mantinelov (aj v dôsledku regulačnej arbitráže) národných predpisov. O to viac je zaujímavejšie inšpirovat' sa v rôznych definíciách.

Podl'a americkej autorky S.A. Winters ide o subjekt (entitu) alebo skupinu subjektov, ktoré bežne financujú svoje záväzky voči osobám majúcim zodpovedajúce pohl'adávky výnosmi plynúcimi z ich novo vzniknutých záväzkov (emisie dlhov) ale podvádzajú tieto osoby, pokial' ide o zdroj financovania záväzku. Schéma vedie k redukcii istiny pohl'adávky (zníženie sumy, s ktorou je spojený nárok na výplatu investície, poznámka autora) akéhokol'vek druhu (preklad autora). ${ }^{3}$

Podl'a Blackovho právnického slovníka (Black's Law Dictionary, 1278, 9th ed. 2009) ide o podvodnú investičnú schému, v ktorej peňažné príspevky vložené neskoršími investormi generujú umelo vysoké dividendy alebo výnosy predchádzajúcim investorom, a tým prit’ahuje d’alšie investície. Peňažné príspevky nových investorov sa používajú priamo na splatenie pohl'adávok alebo vyplácanie úrokov skorším investorom, a to (zvyčajne) bez akejkol'vek obchodnej prevádzky alebo príjem generujúcej činnosti inej ako nepretržité získavanie nových finančných prostriedkov a s tým súvisiaca tvorba nových peňažných fondov (preklad autora). ${ }^{4}$

V rozhodovacej praxi súdov USA existuje generalizované širšie vymedzenie. Podl'a okresného súdu v štáte Connecticut (U.S. District Court for the District of Connecticut) v rámci Ponziho schémy podnik používa na realizáciu platieb investorom peniaze získané od novo pritiahnutých investorov a nie zo ziskov plynúcich z legitímnej obchodnej činnosti (preklad autora). ${ }^{5}$

Substantívnym pôvodným znakom pyramídovej investičnej schémy je skutočnost', že subjekt bežne financuje svoje záväzky svojimi novými záväzkami, zatial' čo svojím veritel'om prezentuje povahu svojej činnosti inak. ${ }^{6}$ Tento znak bol po dlhé obdobie postačujúci pre kvalifikáciu subjektu ako pyramídovej schémy.

Pre podrobnejšiu identifikáciu znakov tzv. finančnej pyramídy je dôležité vychádzat' z komparácie pyramídových schém a stanovit', čo je spoločné pre ich všetky typy, prípadne doplnit' znaky typické iba pre niektoré z nich. ${ }^{7}$

\footnotetext{
WINTERS, S. A. The Law of Ponzi Payouts. Michigan Law Review. 2012, Vol. 111, No. 1, s. 122.

Tamtiež.

Tamtiež.

Tamtiež.

7 V tejto súvislosti je potrebné upozornit' na špecifiká spontánneho, prirodzene sa vyskytujúceho Ponziho systému, v ktorom absentuje manipulátor a rafinovaný podvodný plán, resp. jednotlivcami kontrolovaný experiment a priama manipulácia, a ktorý vychádza zo „stádového“, resp. „lavínového“ správania masy a „samo sa napĺňajúceho proroctva“. Pozri SHILLER, R. J. Investiční horečka-iracionální nadšení na kapitálových trzích (český preklad). Praha: Grada Publishing, a. s., 2010, s. 105. Od tejto schémy je potrebné odlíšit' priamu trhovú manipuláciu, z ktorej má prospech konkrétny subjekt (napríklad šírením
} 
V rámci nášho výskumu uvádzame tieto prima facie indikátory finančných pyramíd ako i špecifické indikátory niektorých finančných pyramíd:

a) Podvodné konanie (ekonomická kriminalita), ${ }^{8}$ využívajúce legislatívne medzery a operačné zlyhania v preventívnej činnosti rôznych orgánov verejného práva (vrátane dohliadacích orgánov); takéto schémy nie sú licencované orgánom dohl'adu (napríklad centrálnou bankou) s ciel'om vyhnút' sa súvisiacim verejnoprávnym požiadavkám obozretného podnikania, informačným povinnostiam voči spotrebitel'om atd'. Ak prevádzkovanie činnosti finančnej pyramídy spadá pod rámec regulovanej činnosti, s ktorou je spojená povinnost' získat' príslušné verejnoprávne povolenie, nepodanie žiadosti o udelenie takého povolenia samo osobe zakladá skutkovú podstatu trestného činu neoprávneného podnikania a súčasne administratívneho deliktu podl'a určitej finančno-právnej regulácie (napríklad môže íst' o porušenie zákona o bankách, zákona o cenných papieroch).

b) Finančné pyramídy obvykle nespadajú pod regulačné predpisy finančného trhu ako verejnoprávne dohliadané subjekty. Niektoré z nich sa však pokúšajú vykonávat' činnost' ako dohliadané subjekty s príslušným povolením, čím získavajú potrebnú kredibilitu u verejnosti, napríklad banky, osobitne subjekty na kapitálovom trhu. Výkon činnosti je legálny (uzavieraný kontrakt nie je contra legem), okrem toho, že vykonávajú skutočné obchodné operácie navyše podvádzajú aj svojich (niektorých) investorov, niekedy bez sl'ubu umelo (neprirodzene) vysokej návratnosti investície.

c) Finančné pyramídy môžu súčasne vykonávat' aj iné - legálne - aktivity.

d) Prítomnost' zámeru osobného obohatenia členov štatutárneho alebo dozorného orgánu.

e) Zneužitie dôvery investorov (organizátor poskytuje „dôveryhodný príbeh“, čím vytvára podmienky pre excitovaný stav investorov, predstavuje príklad úspešného investora v systéme a podporuje sebavedomie potenciálneho klienta); obvykle iba malá čast’ peňažných prostriedkov je investovaná do skutočných aktív.

f) Existencia mechanizmu spočívajúceho v transfere vytvorených peňažných fondov od nových investorov (tzv. regrúti) na tých, ktorí sú v organizačnom usporiadaní schémy vyššie (starší regrúti/skorší klienti, členovia orgánov pyramídovej entity). ${ }^{9}$

g) Nevyhnutnost' splatenia iniciačných vkladov investormi (v prípade viacúrovňovej marketingovej pyramídy ide o počiatočné nákupy potrebné pre vstup do schémy). Prví investori sú skeptickí a spočiatku investujú malé finančné obnosy.

h) Deklarácia zavádzajúcich tvrdení o výške výnosu a návratnosti investície (prezentovaný príjem je nad reálne dosiahnutel'nou hranicou). Investorom sa sl'ubuje (v mesačnom, ročnom intervale) vysoký zisk z investície v krátkom období, čo je

zavádzajúcich informácií, klamlivými signálmi o cene spôsobenými neprirodzenými pokynmi na nákup/ predaj finančného nástroja) a ktoré môžu súčasne predstavovat’ finančnú pyramídu na kapitálovom trhu.

8 Z hl'adiska podielu na aktivitách s kryptomenami najviac páchaným podvodom v roku 2019 podl'a spoločnosti Chainalysis bola práve Ponziho schéma. Pozri CHAINALYSIS. The 2020 State of Crypto Crime. January 2020 [online]. [cit. 2020-06-05]. Dostupné na: https://go.chainalysis.com/rs/503-FAP-074 /images/2020-Crypto-Crime-Report.pdf.

9 Základnou premisou Ponziho schémy je „okradnút’ B, aby sa vyplatil A“. 
v príkrom rozpore so základnými princípmi štandardného investovania. ${ }^{10} \mathrm{~V}$ tejto súvislosti je však potrebné zdôraznit', že ročná miera návratnosti vždy závisí od okolností na trhu (trhové riziko), preto hoci v niektorých pyramídových schémach slubované sadzby neboli nízke, nemuseli byt' nevyhnutne v rozpore s pevnými úrokovými sadzbami bežne dostupnými na trhu, čím sa pyramídy niekedy stávajú t’ažko čitatel'né aj pre priemerného investora.

i) Nadmerná výplata výnosov z investície má dočasný charakter a je spojená s morálnym hazardom investorov, ktorí očakávajú kontinuitu rovnakých platieb.

j) Trvalo neudržatel'ný systém vedúci ku kolapsu. Činnost' zakladajúca podvodné konanie nie je založená na reálnom obchodnom pláne (pyramídové schémy nie sú navrhnuté tak, aby vytvorili životaschopný subjekt, a preto všetky skrachovali).

k) Nedostatok podrobných informácií dostupných pre investora, na základe ktorých by bolo možné overit' si uskutočnitel'nost' podnikatel'ského zámeru v schéme. Tento stav zakladá následne pochybnosti o tvrdenej investičnej stratégii.

1) Klamlivá reklama a publicita. Regulačné ustanovenia pre subjekty finančného trhu, typicky v kolektívnom investovaní, preto obsahujú v rámci prevencie povinnost', aby akákol'vek propagácia regulovaného investovania obsahovala výrazné upozornenie, že hodnota investície sa môže aj znížit a návratnost' pôvodne investovanej sumy nie je zaručená alebo že s investíciou je spojené aj riziko. ${ }^{11}$

m) Podozrivé okolnosti akvizície klientov pre investíciu, napríklad prostredníctvom telefonických hovorov, internetu apod.

n) Pravdepodobnost' úspechu pre nových účastníkov pyramídovej schémy úmerne klesá s vel'kost’ou pyramídy bez ohl’adu na úkony jednotlivých účastníkov.

Obdobne americká Komisia pre cenné papiere a burzy (U.S. Securities and Exchange Commission/SEC) pomenúva sedem varovných signálov pre investora (,red flags“"), ktoré v sebe zahŕňajú vzájomne spoločné znaky Ponziho schém (vysoká návratnost' investície s malým alebo žiadnym rizikom, pravidelné vy̌šie kladné výnosy bez ohl'adu na trhový vývoj, výkon činnosti bez verejnoprávnej registrácie/licencie, zahmlievané zložité investičné stratégie, komplikácie v písomnej komunikácii s klientom, t’ažkosti $\mathrm{s}$ vyplácaním výnosov). ${ }^{12}$ Osobitne by sme mohli identifikovat' daalšie znaky finančných pyramíd na trhu cenných papierov (adresnost' skupiny klientov, nie cielenie na masy). Detekcia pyramíd môže byt' napriek tomu komplikovaná, pretože niektoré znaky nie sú na prvý pohlad zrejmé.

10 Trojuholník investora na finančnom trhu s vrcholmi: riziko - výnos - likvidita, ktoré nie sú dosiahnutel'né kumulatívne vo svojom maxime.

11 V Slovenskej republike pozri napríklad § 151 ods. 2 zákona č. 203/2011 Z. z. o kolektívnom investovaní v znení neskorších predpisov.

12 U.S. SECURITIES AND EXCHANGE COMMISSION. Ponzi Schemes. October 9. 2013 [online]. [cit. 2020-06-13]. Dostupné na: https://www.sec.gov/fast-answers/answersponzihtm.html\#RedFlags 


\section{FINANČNÉ PYRAMÍDY VERZUS PYRAMÍDY NA FINANČNOM TRHU A ĎALŠIA TYPOLÓGIA FINANČNÝCH PYRAMÍD}

Ponziho schémy môžu pôsobit' na finančnom trhu a poskytovat' služby inak podliehajúce finančno-právnej regulácii, alebo vykonávajú svoju činnost' mimo regulačného rámca finančného trhu ako bežný podnikatel'ský zámer. Niekedy, najmä pri finančných inováciách, je však pomerne zložité determinovat' hranice medzi verejnoprávnou a súkromnoprávnou reguláciou, kedž̌e častokrát nové obchodné modely využívajú ,„̌edé“ legislatívne zóny a pôsobia na hrane existujúcich verejnoprávnych obmedzení. $\mathrm{V}$ rámci kategorizácie finančných pyramíd na finančnom trhu považujeme za významné zaužívané členenie na tieto typy (modely) podl’a postavenia investora: 13

1. model založený na pevnom výnose (fixed-income scheme) ako sporiaci program,

2. model založený na vlastníctve a investovaní finančného aktíva (equity-type scheme) $\mathrm{s}$ investičným rizikom.

$\mathrm{V}$ modeli ad 1 má investor postavenie veritel’a v klasickom obligačnom vzt'ahu s príslubom vyplatenia istiny a pravidelného úroku. Jeho výskyt bol typický aj v bankovníctve, no môže sa vyskytovat' aj na kapitálovom trhu v rámci emisie dlhových cenných papierov s pevným úrokom.

V modeli ad 2 investor zverí finančné prostriedky do úschovy správcu (custodián, investment operator) investičnej schémy na účely ich investovania v mene investora. Príslušný kontrakt namiesto prísl'ubu výplaty istiny a pevného výnosu obsahuje príslub výplaty zhodnotenia investície (výnosov, ktoré vyvstanú z investície), pričom je možné aj jej znehodnotenie (neexistencia dlžníckeho vzt’ahu). Investovaná suma je však spreneverená organizátorom tejto schémy.

Ako poznáme z nedávnej minulosti aj v Slovenskej republike, obidva typy (modely) finančných pyramíd sa môžu vyskytnút' na finančnom trhu (prípady DEVÍN BANKA alebo PDSI HOLDING) i mimo neho (AGW, B.M.G INVEST, DRUKOS VÝNOS).

\section{FINANČNÉ PYRAMÍDY A OCHRANA INVESTORA}

Pre preventívnu právnu ochranu investorov je dôležitý regulačný prístup zákonodarcu, či sa rozhodne niektoré znaky konania typického pre finančné pyramídy postavit' contra legem. V legislatíve podl'a nášho názoru možno rozlišovat', či ide o všeobecnú prevenciu pred finančnými pyramídami, ktoré využívajú právnym poriadkom uznané formy obchodných spoločností (resp. družstvo) alebo iné formy účasti na podnikaní (tiché spoločenstvo), alebo či ide o špecifické zákazy, ktoré subsumujú protiprávnu činnost' takých investičných schém, ktoré pôsobia na finančnom trhu a usilujú sa získat' dôveryhodnost' ako licencované subjekty pod verejným dohl'adom konkrétnych autorít.

13 WINTERS, S. A. The Law of Ponzi Payouts. Michigan Law Review. 2012, Vol. 111, No. 1, s. 123-124 a $137-138$. 
Všeobecnú prevenciu v Slovenskej republike predstavujú najmä kogentné ustanovenia Obchodného zákonníka (zákon č. 513/1991 Zb. v znení neskorších predpisov) upravujúce

1. zmluvu o tichom spoločenstve ( $\$ 675$ v spojení $§ 263$ ods. 1 v znení zákona č. 500/2001 Z. z. ${ }^{14}$ ), ktorých obsahom je právo kontroly tichého spoločníka (dozvediet' sa o spôsobe hospodárenia so svojím vkladom) a zodpovedajúce informačné povinnosti podnikatel'a voči spoločníkovi,

2. zákaz vrátania vkladu spoločníkovi (§ 67j v znení zákona č. 87/2015 Z. z., § 123 ods. 3 v znení zákona č. 87/2015 v úprave spoločnosti s ručením obmedzeným, $\S 179$ ods. 2 v znení zákona č. 500/2001 Z. z. v úprave akciovej spoločnosti),

3. zákaz vyplácania úrokov z vkladov do spoločnosti a preddavkov na dividendu/podiel na zisku ( $\$ 123$ ods. 2 v úprave spoločnosti s ručením obmedzeným, $§ 179$ ods. 5 v úprave akciovej spoločnosti, $\$ 223$ ods. 8 v úprave družstva; všetky v znení zákona č. 500/2001 Z. z.); navyše v úprave akciovej spoločnosti existuje od prijatia Obchodného zákonníka aj zákaz vydávania akcií, s ktorými by bolo spojené právo na určitý úrok nezávisle od hospodárskych výsledkov spoločnosti (§ 159 ods. 2).

V právnej regulácii finančného trhu existuje viacero osobitných ustanovení, ktoré slúžia ako prevencia pred vytváraním pyramídových schém. Základnou právnou prevenciou pred pyramídovou schémou na finančnom trhu je ustanovenie legislatívneho zákazu poskytovat' pôžičky (resp. úvery) a prijímat' vklady bez príslušného právoplatného povolenia udeleného regulátorom trhu. ${ }^{15}$ Medzi všeobecnú prevenciu možno zaradit' aj ustanovenia o ochrane označení dohliadaných subjektov a ich cudzojazyčných prekladov (napríklad slová „,banka“, ,,sporitel’ňa“, ,,poist'ovňa“) pred používaním v obchodných menách nelicencovaných subjektov. V rámci licenčného procesu orgán dohl'adu preskúmava reálnost' (životaschopnost') predloženého obchodného plánu, ktorý tvorí prílohu žiadosti o udelenie príslušného povolenia. ${ }^{16}$ Okrem toho možno identifikovat' prevenčné ustanovenia imanentné konkrétnemu finančnému produktu ${ }^{17}$ alebo

14 S účinnost'ou tohto zákona od 1. januára 2002, teda následne ako reakcia na krach prvých „nebankoviek“. Podl'a dôvodovej správy k novelizačným bodom 281 a 298 návrhu tohto zákona ciel'om úpravy „,je zamedzit' zneuživaniu tohto inštitútu nebankovými subjektami vykonávajúcimi služby ekvivalentné bankovým bez príslušného povolenia. “ Pozri Dôvodová správa osobitná čast' k zákonu č. 500/2001 Z. z. z 3. októbra 2001, ktorým sa mení a dopíňa Obchodný zákonník v znení neskorších predpisov, dostupné zo systému ASPI [cit. 2020-06-05].

15 V Slovenskej republike porovnaj s $§ 3$ ods. 1 a 2 zákona č. 483/2001 Z. z. o bankách a o zmene a doplnení niektorých zákonov v znení neskorších predpisov:

„(1) Bez bankového povolenia nemôže nikto prijímat' vklady, ak osobitný predpis neustanovuje inak. Bez. bankového povolenia nemôže nikto poskytovat' z vkladov úroky alebo iné odplaty, ktoré sú daňovým výdavkom podl'a osobitného predpisu.

(2) Bez bankového povolenia nemôže nikto poskytovat' úvery a pôžičky v rámci predmetu svojho podnikania alebo predmetu inej svojej činnosti, z návratných peňažných prostriedkov získaných od iných osôb na základe verejnej výzvy, ak osobitný predpis neustanovuje inak."

16 Pozri napríklad $\$ 7$ ods. 2 písm. g) zákona č. 483/2001 Z. z. o bankách a o zmene a doplnení niektorých zákonov v znení neskorších predpisov.

17 Najmä zákaz pre emitenta používat' pri propagácii vydávania svojich cenných papierov nepravdivé alebo zavádzajúce informácie alebo zamlčovat' skutočnosti dôležité pri rozhodovaní o nadobúdaní cenných papierov, najmä ponúkat' výhody, ktorých splnenie nemôže zaručit' alebo ktoré nie sú v súlade so zákonom, alebo uvádzat' nesprávne údaje o svojej hospodárskej situácii, ktorý súvisí s plnením si tzv. prospektovej 
priame zákazy vytvárania mechanizmov v podobe odmien, ciel'ov predaja, alebo iných nástrojov, ktoré môžu predstavovat' stimul, aby sa klientovi odporúčal určitý finančný produkt, a to pri výkone finančného sprostredkovania prostredníctvom siete finančných agentov. ${ }^{18}$ Následná ochrana sa prejavuje v represívnej možnosti orgánu dohl'adu porušenia týchto zákazov administratívnoprávne sankcionovat' (osobitne vo vzt’ahu k porušeniu spotrebitel'ských práv), ${ }^{19}$ ktorá je ustanovená v každom zákone regulujúcom finančný trh osobitne.

Národne špecifickým ochranným inštitútom na finančnom trhu bola verejná ponuka majetkových hodnôt ${ }^{20}$ ktorý mal slúžit' v čase prijatia zákona o cenných papieroch ako prevenčný nástroj na čiastočnú reguláciu rozličných investičných aktivít neslávne známych nebankových subjektov z konca devät'desiatych rokov. Koncepčne neupravoval konkrétny regulovaný spôsob zhromažd’ovania peňažných prostriedkov, schváleniu Národnej banky Slovenska však podliehal prospekt investície. Pre propagáciu investície platilo pravidlo, že v prostriedkoch zverejnenia nesmela byt' publikovaná taká verejná ponuka, ktorá pre investora obsahovala zjavnú alebo skrytú podmienku získania d’alších investorov. Z takto získaných verejných prostriedkov sa súčasne nesmeli poskytovat' úvery a pôžičky. ${ }^{21}$

Väčšina finančných pyramíd na finančnom trhu nie je zúčastnená na garančnej schéme ochrany investícií. Na druhej strane, investor sám musí byt' ostražitý a reflektovat' varovné signály investície. Pokial' ide o faktickú kategorizáciu investorov, u finančných pyramíd môžeme rozdelit' v určitom životnom cykle zúčastnené osoby na vít’azov (osoby, ktoré podvod zorganizovali a niekedy aj prví investori v schéme, ktorí získajú okrem istiny aj výnos) a porazených (obete). Porazenými sú pritom ostatní investori, ktorých je väčšina a ktorí prišli o istinu alebo jej väčšiu čast'.

\section{ZÁVER}

Ako bolo v príspevku naznačené, finančno-právna regulácia činností, ktoré zavádzajú investora (nielen na finančnom trhu) podvodným spôsobom s ciel'om vylákat' jeho investičný vklad, nie je na úrovni Európskej únie právne riešená a zodpovednost' za postih takéhoto konania je prevažne v rukách orgánov činných v trestnom konaní.

povinnosti pri verejnej ponuke cenných papierov (§ 112 ods. 1 zákona č. 566/2001 Z. z. o cenných papieroch a investičných službách a o zmene a doplnení niektorých zákonov v znení neskorších predpisov).

18 Pozri § 32 ods. 6 zákona č. 186/2009 Z. z. o finančnom sprostredkovaní a finančnom poradenstve a o zmene a doplnení niektorých zákonov v znení zákona č. 282/2017 Z. z. Fakticky ide o zákaz viacúrovňového marketingu pri predaji konkrétnych finančných produktov.

19 KORONCZIOVÁ, A. Sankcie v oblasti ochrany finančného spotrebitel'a. In: Banskobystrické zámocké dni práva na tému: Identifikácia únosnej miery autonómie právnych odvetví a súčasnej potreby ich synergie. Zborník. Banská Bystrica: Belianum, 2018, s. 164-172.

20 Obsiahnutá v $\$ 126$ až 130 zákona č. 566/2001 Z. z. o cenných papieroch a investičných službách a o zmene a doplnení niektorých zákonov v znení do 21. júla 2013 (do účinnosti zákona č. 206/2013 Z. z.)

21 ČUNDERLÍK,L'.K niektorým inovatívnym a atypickým modelom správy majetku na finančnom trhu. In: ČUNDERLÍK, L. - ČUNDERLÍK ČERBOVÁ, V. - DAUDRIKH, Y. - HESEKOVÁ, S - KATKOVČIN, M. MAZÚR, J. Inovatívne a atypické modely správy majetku na finančnom trhu a súvisiace otázky. Praha: Leges, 2019, s. 91-92. 
Právna úprava finančného trhu (v rámci tzv. práva finančného trhu) 22 je v tomto smere skôr reziduálna a založená na regulácii postavenej na pravidlách (rules based regulation) t. j. na konkrétnych kogentných normách upravujúcich zákazy určitého konania kazuistickým spôsobom (ako bezprostredná legislatívna reakcia). Činnost' národného orgánu dohl'adu v podobe priebežného publikovania ,warningov“ na podozrivé subjekty je iba doplnkový prevenčný nástroj. Súčasnou výzvou je podl’a nášho názoru zavádzanie finančných inovácií (osobitne založených na technológiách, tzv. FinTech), ktoré sa snaží orgán regulácie a dohl'adu nad finančným trhom identifikovat' a potenciálne usmernit' v regulácii. ${ }^{23} \mathrm{O}$ to väčšiu úlohu tohto orgánu preto vidíme v rovine všeobecných sankčných kompetencií, ${ }^{24}$ ktorými sa postihujú konania síce explicitne nepomenované, avšak spočívajúce v akýchkol'vek porušeniach spotrebitel’ských práv.

Doc. JUDr. Lubomír Čunderlík, PhD.

Právnická fakulta Univerzity Komenského v Bratislave

lubomir.cunderlik@flaw.uniba.sk

22 MRKÝVKA, P. Determinace a diverzifikace finančního práva. Brno: Masarykova univerzita, 2012, s. 197.

23 SROKOSZ, W. Law and Innovations on the Financial Market. In: MRKÝVKA, P. - GLINIECKA, J. - TOMÁŚSKOVÁ, E. - JUCHNIEWICZ, E. - SOWIŃSKI, T. - RADVAN, M. (ed). The financial law towards challenges of the XXI century: (conference proceedings). Brno: Masaryk University, Faculty of Law, 2020, s. 635 a nasl.

24 BOHÁČ, R. Následky porušení finančního práva. In: KARFÍKOVÁ, M. a kol. Teorie finančního práva a finanční vědy. Praha: Wolters Kluwer ČR, 2018, s. 105 a nasl. 